\title{
Актуальні питання нафтогазової галузі
}

УДК 622.279 .5

DOI: $10.31471 / 1993-9973-2020-3(76)-7-22$

\section{УЗАГАЛЬНЕННЯ ОСНОВНИХ ДОСЛІДЖЕНЬ 3 ПІДВИЩЕННЯ ВУГЛЕВОДНЕВИЛУЧЕННЯ ГАЗОКОНДЕНСАТНИХ РОДОВИЩ ПРИ ПРУЖНОВОДОНАПІРНОМУ РЕЖИМІ}

\author{
${ }^{1}$ С. В. Матківський*, ${ }^{2}$ О. Р. Кондрат

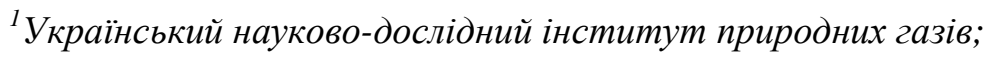 \\ 61010, м. Харків, Гімназійна набережна, 20, тел./факс (05773) 31755, \\ e-mail: matkivskyi.sergey@ndigas.com.ua \\ ${ }^{2}$ ІФНТУНГ; 76019, м. Івано-Франківськ, вул. Карпатська, 15; тел. (03422) 42195, \\ e-mail: kondrat@nung.edu.ua
}

\begin{abstract}
Проблема контролю та попередження обводнення покладів родовищ Украӥни набуває все більшої актуальності. Вирішення даної проблеми є одним із напрямків збільшення вуглеводневилучення з виснажених газових родовищ в умовах авктивного водонапірного режиму. Експлуатація видобувних свердловин ускладнюється накопиченням рідини на вибої, щуо призводить до значних ускладнень в прочесі їх роботи та подальшого передчасного припинення фонтанування. Обводнення свердловин зумовлює необхідність виконання робіт з інтенсифікації винесення рідини з вибою на поверхню чи ізоляції припливу пластових вод. Враховуючи значні залишкові запаси защемленого водою газу, актуальним є удосконалення існуючих та розробляння нових технологій дорозробки виснажених родовищ в умовах інтенсивного обводнення з метою забезпечення максимальних коефіцієнтів вилучення вуглеводнів. В даній роботі узагальнено вітчизняні та зарубіжні технології розробки родовищ в умовах прояву пружноводонапірного режиму та проаналізовано основні недоліки та переваги існуючих методів інтенсифікації припливу вуглеводнів в умовах обводнення газових та газоконденсатних свердловин. Проаналізовано основні фактори, щуо визначають причини та характер обводнення продуктивних пластів та шляхи його попередження. За результатами аналізу лабораторних та експериментальних досліджень встановлено механізм поведінки защемленого пластовою водою газу, однак не достатньо вивчене питання визначення локалізації залишкових запасів вуглеводнів. Враховуючи вищенаведене, обтрунтовано необхідність створення і використання постійно діючих геолого-технологічних моделей (ПДГТМ), щз забезпечить більш повне вилучення залишкових запасів газу з виснажених родовищ в умовах інтенсивного просування пластової води в продуктивні пласти. В разі адаптації тривимірної моделі до фактичних даних історії розробки та відтворення динаміки прориву пластової води в експлуатачійних свердловинах з'являється можливість визначення найбільш перспективних зон та ділянок родовища, колектори яких характеризуються високими фільтрачійно-смнісними властивостями та значними залишковими запасами газу. Використання постійно діючої геолого-технологічної модель родовища дає змогу напраџювати можливі шляхи довилучення залишкових запасів газу із защемлених пластовою водою зон, вдосконалити існуючі технології розробки та забезпечити максимальні коефіцієнти вуглеводневилучення.
\end{abstract}

Ключові слова: родовище, запаси газу, обводненість, водонапірний режим, 3D модель. 
Проблема контроля и предупреждения обводнения залежей месторождений Украины получает все большую актуальность. Решение данной проблемы является одним из направлений увеличения коэффициентов извлечения углеводородов из истощенных газовых месторождений в условиях активного водонапорного режима. Эксплуатация добывающих скважин осложняется накоплением жидкости на забое, что приводит к значительным осложнениям в процессе их работы и дальнейшему преждевременному прекращению фонтанирования. Обводнение скважин обуславливает необходимость выполнения работ по изоляцчии притока пластовых вод. Учитывая значительные остаточные запасы защемленного водой газа, актуальным является совершенствование существующих и создание новых технологий разработки истощенных месторождений в условиях активного водонапорного режима с иелью обеспечения максимальных коэффициентов извлечения углеводородов. В данной работе обобщены отечественные и зарубежные технологии разработки месторождений в условиях проявления упруговодонапорного режима и проанализированы основные недостатки и преимущества существующих методов интенсификации притока углеводородов в условиях обводнения газовых и газоконденсатных скважин. Проанализированы основные факторы, определяющие причины и характер обводнения продуктивных пластов и пути их предотвращения. По результатам анализа лабораторных и экспериментальных исследований установлен механизм поведения защееленного пластовой водой газа. Однако, недостаточно изучен вопрос локализачии остаточных запасов углеводородов. С учетом вышеизложенное обоснована необходимость в создании и использовании постоянно действуюших геолого-технологических моделей (ПДГТМ), что обеспечит более полное извлечение остаточных запасов газа из истощенных месторождений в условиях интенсивного продвижения пластовой воды в продуктивные пласты. В случае адаптации трехмерной модели к фактическим данным истории разработки и воспроизведения динамики прорыва пластовой воды в эксплуатационные скважины позволит определить наиболее перспективные участки залежи, коллектора которых характеризуются более высокими фильтрационно-емкостными свойствами и значительными остаточными запасами газа. Использование постоянно действующей геолого-технологической модели месторождения позволяет выработать возможные пути извлечения остаточных запасов газа с ущемленных пластовой водой зон, усовершенствовать существующие технологии разработки и обеспечить максимальные коэффициенты извлечения углеводородов.

Ключевые слова: месторождение, запасы газа, обводненность, водонапорный режим, 3D модель.

The problem of monitoring and preventing deposit inundation is becoming increasingly important in Ukraine. The solution to this problem is one of the ways to ensure the energy independence of the state. The operation of producing wells is complicated by the accumulation of liquid at the bottom. Subsequently, it leads to premature shutdown of the wells. Inundation determines the need to isolate the influx of formation water. Considering the significant residual reserves of gas trapped in water, it is important to improve existing technologies and to develop new ones for the development of depleted fields under the conditions of dynamic water drive in order to ensure maximum hydrocarbon recovery rates. This paper summarizes domestic and foreign field development technologies under water pressure conditions and analyzes the main disadvantages and advantages of the existing methods of stimulating hydrocarbon inflows in waterlogged gas and gas condensate wells. The main factors that determine the causes and nature of flooding of productive formations and ways to prevent them are analyzed. Based on the results of the analysis of laboratory and experimental studies, the behavior of gas trapped by brine water has been established.But the issue of determining the localization of residual reserves has not been studied sufficiently. Considering the above mentioned ideas, the author asserts the necessity to and to use geological and technological models constantly. It ensures better extraction of the residual gas from depleted fields under the condition of intensive advance of reservoir water into productive formations. In the case of adapting the three-dimensional model to the actual data of the production history and the simulation of the exact breakthrough of produced water in production wells, there comes the possible to determine the most promising zones and sections of the field, the reservoirs of which are characterized by the best filtration-capacitive properties and significant gas reserves. The use of a constantly operating geological and technological model of the field will make it possible to develop ways of extracting the residual gas reserves trapped in produced water, to improve existing production technologies and to ensure maximum recovery factors.

Keywords: field, gas reserves, water cut, water drive, 3D model.

\section{Вступ}

Переважна більшість газоконденсатних родовищ АТ "Укргазвидобування" перебуває на завершальній стадії розробки, яка характеризується інтенсивним обводненням продуктивних пластів та експлуатаційних свердловин, що призводить до передчасного виходу свердловин 3 експлуатації, защемлення в обводнених зонах значної кількості природного газу та зниження поточного та кінцевого коефіцієнта газоконденсатовилучення.
Більшість родовищ природних газів характеризується певним проявом пружноводонапірного режиму, що обумовлює активне надходження в газонасичені поклади підошовних чи крайових вод, внаслідок чого в продуктивних пластах утворюються зони із значною залишковою газонасиченістю. Часткове обводнення найбільш високопроникних пластів призводить до зниження продуктивності свердловин. Проведення робіт з ізолювання припливу пластової води в свердловинах досить часто є низькоефе- 
ктивним і не дає очікуваного ефекту. Відновити попередню роботу в таких свердловинах досить складно, тож в більшості випадків їх подальша робота пов'язана 3 переведенням на вищезалягаючі горизонти [1].

У газопромисловій практиці накопичено значний досвід застосування методів контролю за обводненням газових і газоконденсатних покладів і свердловин. Однак, ця проблема залишається актуальною та важливою на поточний час $[1,2]$ [Багато про такі проблеми сказано в роботі Р.М. Кондрата «Газоконденсатоотдача пластов»].

\section{Постановка проблеми}

Відомі методи розробки газових родовищ в умовах водонапірного режиму та експлуатації свердловин із значною кількістю рідини в продукції характеризуються недостатньою ефективністю. Тому доцільно провести дослідження можливих напрямків вдосконалення існуючих i розробки нових технологій дорозробки виснажених родовищ в умовах прояву пружноводонапірного режиму, а також методів інтенсифікації винесення рідини з обводнених свердловин на основі створення постійно діючих геолого-технологічних моделей 3 метою ефективного планування основних геологотехнологічних заходів та раціонального використання надр.

\section{Формування цілей статті}

Ціллю даної статті є узагальнення вітчизняних і зарубіжних технологій розробки родовищ вуглеводнів в умовах пружноводонапірного режиму та удосконалення методів контролю за обводненням газових і газоконденсатних покладів і свердловин з метою збільшення коефіцієнтів вуглеводневилучення.

\section{Виклад основного матеріалу}

Переважна більшість газоконденсатних родовищ України знаходиться на завершальній стадії розробки та характеризується вибірковим обводненням продуктивних пластів і свердловин в умовах низьких пластових тисків. Проблема обводнення газових та газоконденсатних свердловин $\epsilon$ надзвичайно актуальною на даний час не тільки для нафтогазової галузі України, але і для світової практики видобування природних вуглеводнів.

Обводнення свердловин може бути пов'язане як із “аварійним” проривом води 3 водоносних пластів через неякісне кріплення обсадних колон свердловин, так і неконтрольованим проривом пластової води через високо- проникні пропластки продуктивного покладу [2].

Основні фактори, що визначають характер та причини обводнення пластів та свердловин, поділяються на природні та технологічні.

До природних факторів передчасного обводнення відносять геологічну будову пласта та покладу, тип колектора та його фільтраційноємнісні властивості, властивості пластових флюїдів, механізм їх фільтрації в пористому середовищі тощо.

Шляхи обводнення свердловин 3 урахуванням природних факторів наступні:

- “язики" просунення підошовної чи контурної води в зонально-неоднорідному пласті;

- “конуси” підошовної води в однорідному пласті;

- високопроникні пласти в багатопластових об'єктах чи пропластки в шарувато-неоднорідному пласті;

- високопроникні тріщини в порово-тріщинуватому чи тріщинувато-поровому пласті.

Враховуючи особливості експлуатації та технічний стан свердловин, шляхи передчасного чи аварійного їх обводнення наступні [3]:

- негерметичність цементного стакана на вибої свердловини, що обумовлює надходження води 3 нижчезалягаючого водоносного пласта;

- встановлення нераціональних технологічних режимів експлуатації видобувних свердловин;

- дефекти експлуатаційної колони, обумовлені неякісним або неповним іiі цементуванням та ії корозією;

- негерметичності експлуатаційної колони, що зумовило надходження або перетікання води із одного пласта в інший чи в свердловину.

3 метою винесення газорідинної суміші 3 вибою газових та газоконденсатних свердловин використовують спінювальні поверхневоактивні речовини, газліфтний спосіб експлуатації, плунжерний ліфт, оптимізацію гирлових тисків тощо. Однак, використання даних методів $є$ недостатньо ефективним та має короткочасний ефект.

Проблема попередження просування пластових вод і обводнення свердловин на родовищах України набуває все більшої актуальності. Вирішення даної проблеми $є$ одним із напрямків забезпечення енергетичної незалежності держави.

Матеріали гідрогеологічних досліджень, а також дані про підземні води, отримані по свердловинах пошуково-розвідувального буріння, 3 яких при випробуванні отримані припливи 
пластових вод, дозволяють охарактеризувати особливості гідрогеологічної системи в межах родовища.

Обводнення продуктивних горизонтів за умови прояву водонапірного режиму є цілком природним процесом, однак він має бути контрольованим. Для зменшення негативного впливу водонапірного режиму на процес розробки покладу необхідно здійснювати контроль за просуванням пластових вод і його регулювання. Такий контроль повинен спиратися на результати аналізів розробки покладів та відповідні висновки та залежності.

До основних методів контролю за процесом розробки родовища відноситься побудова залежності приведеного пластового тиску від накопиченого видобутку газу з родовища $[1,4]$. Використовуючи графоаналітичну залежність, встановлюють режим розробки родовища, визначають початкові та залишкові дреновані запаси газу та оцінюють активність пластової водонапірної системи при надходженні в продуктивні поклади пластових вод, а також оцінюють характер дренування продуктивних покладів [5-6].

Згідно 3 дослідженнями А. Х. Мірзаджанзаде та ін. [5, 7-8] на початковій стадії розробки газового родовища в умовах пружноводонапірного режиму падіння пластового тиску може бути аналогічним газовому режиму розробки, що пояснюється існуванням певного градієнта тиску, за якого можлива така схожість. Залежність приведеного пластового тиску в функції накопиченого видобутку газу має лінійний характер. Однак, при активному водонапірному режимі та високій проникності газоносних пластів дана подібність відсутня.

Розробка газоконденсатних родовищ в умовах пружноводонапірного режиму характеризується нерівномірним переміщенням газоводяного контакту (ГВК) в залежності від фільтраційно-ємнісних характеристик продуктивних пластів [9]. Це призводить до "язикового" обводнння та защемлення водою залишкових запасів газу. Коефіцієнт вилучення газу при пружноводонапірному режимі на родовищах АТ "Укргазвидобування" в середньому складає 60-70\%. Через неповне його витіснення водою в обводненій частині покладу залишається мікрозащемлений газ. Також значний об'єм макрозащемленого газу зумовлений нерівномірним просуванням фронту води [10]. Схема переміщення газоводяного контакту (ГВК) в процесі розробки газоконденсатного родовища зображена на рисунку 1.
Визначення положення ГВК є важливим завданням контролю, без якого неможлива раціональна розробка покладів. Вибір оптимального комплексу контролю за ГВК повинен базуватися на сучасних науково-технічних досягненнях і промисловому досвіді [3].

Відомі методи, які використовуються для попередження просування пластових вод та боротьби з обводненням експлуатаційних свердловин, спрямовані на мінімізацію негативного впливу пружноводонапірного режиму на процес розробки та збільшення коефіцієнтів вуглеводневилучення.

Розрізняють наступні методи боротьби 3 просуванням пластових вод [11]:

- перехоплення пластових вод 3 використанням спеціальних свердловин, які пробурені на початковому контурі газоносності;

- створення на окремих ділянках родовища, або цілого родовища непроникних екранів для пластової води шляхом закачування через нагнітальні свердловини в'язких чи водоізолюючих агентів;

- зменшення відборів природного газу 3 ділянок родовища, які контактують 3 водоносним басейном, шляхом закриття частини видобувних свердловин та збільшенням темпів відбору із зон сповільненого просування пластових вод [3].

Найважливішим параметром прогнозування видобутку газу та кінцевого коефіцієнта вуглеводневилучення газоконденсатних покладів $\epsilon$ коефіцієнт залишкової насиченості пор защемленим газом. Лабораторні експерименти та розрахунки матеріального балансу демонструють, що насиченість пор в зоні обводнення продуктивної частини покладу може сягати 50 відсотків їх об'єму.

Експериментальними дослідженнями Гофен та ін. [12] у 1952 р. на пробах керну встановили, що насиченість пор защемленим газом може складати 15-50 \% для різних пористих середовищ. В проведених експериментах авторами вивчено вплив початкового насичення пор водою на насичення пор защемленим газом у випадку інтенсивного обводнення пластів та защемлення частини залишкового газу. За результатами проведених досліджень на двох зразках пісковика при різних початкових насиченнях пор водою та защемленим газом встановлено, що початкова водонасиченість не впливає на насичення пор защемленим газом.

У 1963 році Керічі, Чюччі та Лонг [13] було досліджено насиченість защемленим газом зцементованих та незцементованих пісковиків на зразках керну. Середнє залишкове насичення 


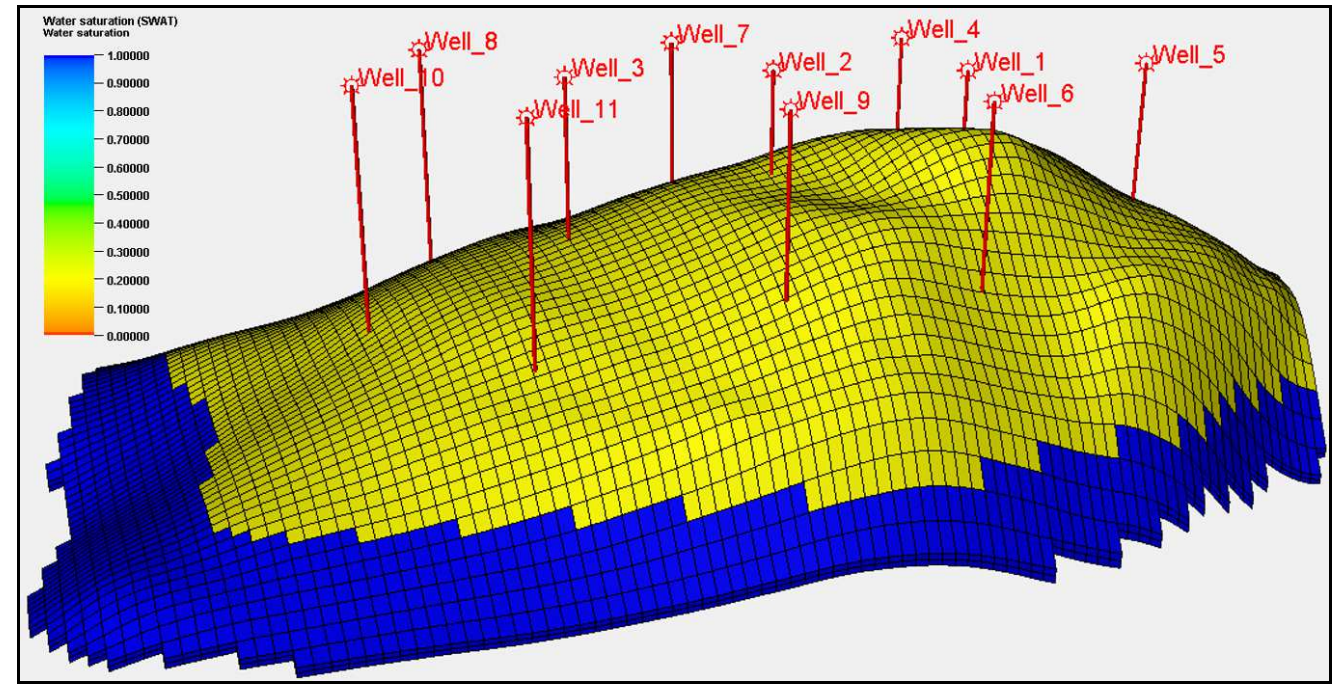

a)

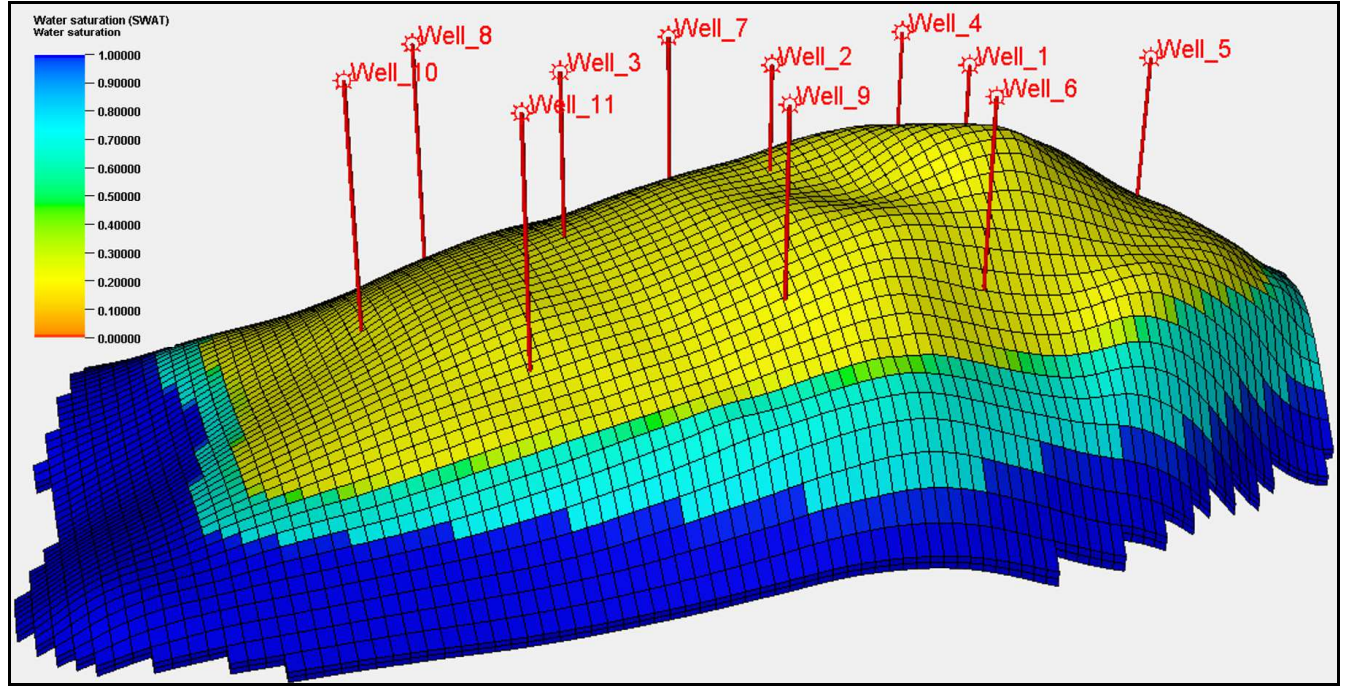

б)

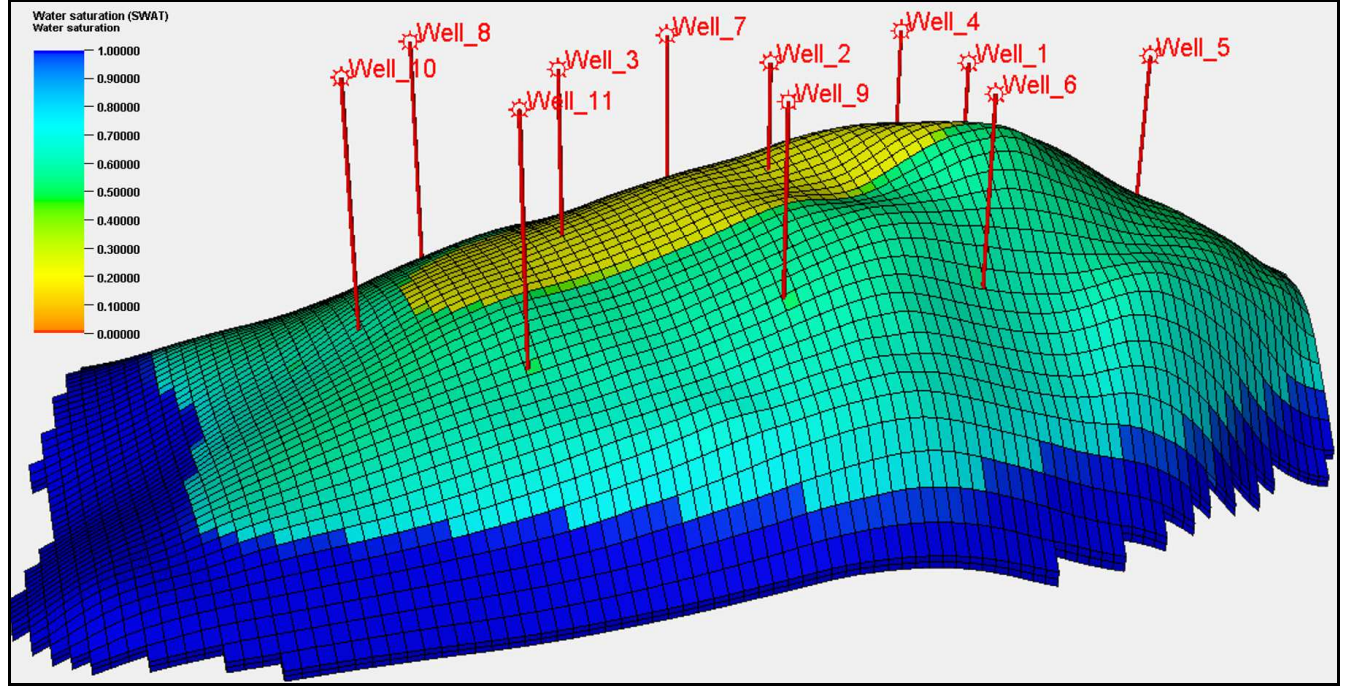

B)

а) до початку розробки; б) зниження початкового пластового тиску на 50\%;

в) зниження початкового пластового тиску $75 \%$

Рисунок 1 - Схема переміщення газоводяного контакту (ГВК)

у процесі розробки газоконденсатного покладу 
пор защемленим газом грунтувалося на розрахунках матеріального балансу при декількох значеннях тиску. Враховуючи, що виснаження газоконденсатних покладів відбувається нерівномірно, для характерзування насичення пор зразків керну дослідниками введено поняття середньої залишкової газонасиченості защемленим газом.

3 метою достовірного визначення початкових запасів газу Брунс та Агарвал та ін. [14] в 1965 році дослідили вплив пружноводонапірного режиму на характер залежності $P n л / z$ від Qнак для газового резервуару. Дослідники проілюстрували, що ті фактори, які обумовили зниження тиску в резервуарі та певним чином спричинили затримання просування пластових вод, призвели до збільшення коефіцієнта вилучення газу. Також було встановлено, що кінцевий коефіцієнт вилучення газу залежить від темпу видобутку газу, залишкового насичення пор газом, продуктивності водонапірної системи та проникності пластів.

Для прогнозування видобутку газу в умовах водонапірного режиму Kнаn та ін. [15] в 1968 році розробили двофазну двовимірну модель. Цю модель було використано для вивчення впливу неоднорідності, продуктивності водоносних горизонтів та темпів видобутку газу. Аналізуючи результати проведених досліджень, зроблено висновок про те, що коефіцієнт вилучення газу є функцією темпів видобутку газу, продуктивності водоносних горизонтів та неоднорідності продуктивних покладів як за товщиною, так і за площею. Результати досліджень добре корелюються з результатами Агарвала щодо темпів видобутку газу та продуктивності водонапірної системи.

Аналіз результатів проведених досліджень та експериментів на основі досліджень розробки покладів в умовах пружноводонапірного режиму дав підстави зробити висновок про те, що в процесі просування пластової води защемляються значні об'єми газу. Щоб досягнути мобільності залишкового защемленого водою газу, необхідно забезпечити насиченість пор вище мінімально необхідного значення, при якому газ починає рухатись. Критичне насичення пор защемленим газом для різних типів порід з різною пористістю, різними відносними фазовими проникностями буде різним. Різниця між початковим та кінцевим значення насиченням мобільним газом пояснюється затримкою міграції природного газу через просування пластової води та защемлення частини його об'єму. Чисельне моделювання розробки продуктивних покладів може допомогти в корект- ній оцінці критичного насичення защемленим газом та дасть змогу коректно підібрати технологію, яка забезпечить вилучення залишкового газу та збільшення кінцевого коефіцієнта вуглеводневилучення.

Протягом багатьох років досліджень процесів розробки родовищ вуглеводнів були запропоновані три основні методи для збільшення видобутку газу із газових родовищ.

Одним із таких методів є видобуток залишкового защемленого газу шляхом продовження експлуатації обводнених свердловин 3 наступним вилученням газу з газорідинної суміші [16]. Цей метод характеризується значними недоліками. Основний недолік пов'язаний з утилізацією великих об'ємів видобутої пластової води в порівнянні з видобутими об'ємами защемленого газу.

Другий метод - це сумісне видобування газу та води. У цьому способі газ видобувають i3 свердловин, які знаходяться гіпсометрично вище та експлуатуються $з$ газової частини покладу. Видобуток води здійснюється з свердловин, які розміщені на межі газоводяного контакту [17]. Цей метод ефективний для газових родовищ 3 малоактивною та активною водонапірними системами.

За третім методом газ видобувають із значно більшими темпами в порівнянні $з$ швидкістю припливу води. Мета цієї технології полягає в тому, що у стислі терміни необхідно вилучити якомога більше газу до моменту прориву пластової води та обводнення продуктивних пластів і експлуатаційних свердловин. Згідно проведених досліджень [18] встановлено, що збільшення темпів видобутку газу не завжди призводить до збільшення коефіцієнта вуглеводневилучення та залежить від фільтраційноємнісних характеристик колектора та зональної неоднорідності продуктивних пластів.

Однією з успішних методик в області активної дії на водонапірний режим для виснажених родовищ вуглеводнів є закачування вуглекислого газу $\left(\mathrm{CO}_{2}\right)$ в продуктивний пласт [19].

Технологія використання вуглекислого газу для витіснення залишкового газу защемленого водою з газових та газоконденсатних покладів, які розробляються в умовах водонапірного режиму, достатньо вивчена та успішно використовується в світі.

Враховуючи те, що густини вуглекислого газу та води значно відрізняються, постійний процес закачування $\mathrm{CO}_{2}$ на границі газоводяного контакту може частково запобігти уведенню води в продуктивні поклади. Методика закачування вуглекислого газу полягає в тому, щоб 
створити штучний бар'єр між водою та природним газом, який блокуватиме вибіркове просування пластової води і тим самим забезпечить стабільну безводну експлуатацію видобувних свердловин. Впровадження технології закачування вуглекислого газу забезпечує значно вищі коефіцієнти вуглеводневилучення 3 продуктивних покладів газових та газоконденсатних родовищ [20].

До перспективних методів регулювання просування пластової води в продуктивні пласти також відноситься і нагнітання азоту, завдяки якому буде витіснятися защемлений водою газ до видобувних свердловин і водночас буде створюватися додатковий бар'єр між водонапірною системою та газонасиченими покладами.

Значний внесок в дослідження ефективності використання азоту в якості агенту нагнітання зробили Р.М. Кондрат та О.Р. Кондрат. Ефективність даної технології досліджено на спеціально розробленій установці, яка включала високопроникні моделі, низькопроникні моделі, а також неоднорідні моделі. Згідно проведених досліджень нагнітання азоту в обводнені моделі встановлено технологічну ефективність застосування азоту для регулювання процесу просування пластових вод. При нагнітанні азоту в обводненні зони покладу витісняється частина раніше защемленого газу до видобувних свердловин. В зоні нагнітання азоту різко зростає пластовий тиск та створюється додатковий гідродинамічний бар'єр, що ускладнює та сповільнює процес просування пластової води в продуктивні пласти. Чим швидше реалізується технологія нагнітання азоту на родовищі, тим вища ефективність даної технології та значно вищі кінцеві коефіцієнти вуглеводневилучення [21].

Великий внесок в дослідження розробки родовищ, розробка яких ускладнюється вибірковим обводненням, зробили теоретичні та експериментальні роботи Бікмана Є.С. [22, 23, $24,25]$, в яких детально вивчені питання вибіркового обводнення покладів Тимофіївського, Куличихинського Котелевського та Березівського родовищ. На основі проведених теоретичних та експериментальних досліджень обгрунтовано доцільність оптимізації розробки родовищ шляхом нагнітання в приконтактну зону «сухого» газу, в тому числі азоту з метою забезпечення стабілізації видобутку важких вуглеводнів через зниження пластових тисків та активної дії на водонапірний режим.

Застосування технології підвищення вуглеводневіддачі покладу Т-1 Тимофіївського та Куличихинського НГКР шляхом нагнітання азоту дозволило частково підтримувати пластовий тиск в покладах та зменшити активність водонапірної системи та частково сповільнити вибіркове обводнення найбільш проникних пластів за рахунок більш повного охоплення їх витисненням азотом. Впровадження таких заходів при розробці покладу Т-1 вищезазначених родовищ призвело до збільшення коефіцієнтів кінцевої вуглеводневіддачі.

Впровадження технології нагнітання азоту може забезпечити більшу надійність видобувних можливостей родовища. При цьому зменшуються ризики щодо випереджаючого обводнення продуктивних покладів та експлуатаційного фонду свердловин.

Запропоновані технології забезпечуються вітчизняною технікою (обладнання азотних установок, оптимальне розкриття пластів тощо).

Практична реалізація систем оптимізації дорозробки газоконденсатних родовищ в широкому розумінні проблеми дозволить суттєво інтенсифікувати процес видобутку вуглеводнів та вийти на світовий рівень вирішення існуючої проблеми.

Важливе місце в дослідженні розробки родовищ в умовах пружноводонапірного режиму займають теоретичні роботи Бернштейна М. Н Гіматудінова Ш. К., [26], в яких детально вивчені питання фільтрації газорідинної суміші в порових каналах газонасичених пластів.

На збільшення коефіцієнта вилучення защемленого газу пластовою водою також спрямовані лабораторні та експериментальні дослідження Мірзаджанзаде А. Х., Мамєдова Г. А. і Рижика В. М. [27, 28].

Значний внесок в дослідження вторинного видобутку газу зробили Р.М. Кондрат, С.Н. Закіров. Аналізуючи отримані результати проведених досліджень при зниженні тиску нижче тиску заводнення, ними виявлено, що защемлений водою газ починає розширюватися та залишається практично нерухомим [2, 29].

Проектуванню раціональної розробки родовищ природних газів в умовах прояву водонапірного режиму присвячена велика кількість досліджень, а також фундаментальних робіт Кондрата Р. М., Закірова С. Н. та Рассохіна Г. В. [2, 30, 31]. Дослідження процесів, які протікають в продуктивному пласті, певною мірою вирішують питання оцінки газовіддачі пластів при водонапірному режимі.

3 використанням проведених досліджень Р. М. Кондратом та С. Н. Закіровим запропоновано технологію [32], відповідно до якої продовженням процесу експлуатації обводнених све- 
рдловин досягається зниження тиску в зоні дренування обводнених свердловини. Зниження тиску призводить до розширення газу та збільшення насиченості пор защемленим газом, що збільшує фазову проникність за газом. Внаслідок сповільнення просування води в зоні розміщення декількох видобувних свердловин попереджується швидке обводнення інших видобувних свердловин, що призводить до більшого охоплення дренуванням продуктивних покладів та, відповідно, збільшення коефіцієнтів вуглеводневилучення.

Лабораторні дослідження вторинного видобутку газу зазвичай проводилися на однорідних моделях пластів, які не можуть повною мірою характеризувати фізичні процеси, що мають місце під час фільтрації вуглеводнів в неоднорідному пласті.

Значний внесок в удосконалення існуючих технологій вторинного видобутку газу зробили Р. М. Кондрат та О. Р. Кондрат, які вперше встановили якісні та кількісні характеристики процесу видобутку газу з однорідних та неоднорідних резервуарів при зниженні пластового тиску. Дослідження проводилися на однорідних низько- та високопроникних моделях, а також на неоднорідній моделі, яка складалася 3 двох моделей різної проникності. Згідно проведених досліджень було доведено ефективність технологічного методу зниження тиску в обводнених зонах покладу шляхом видобутку з свердловин значних об'ємів води. Після обводнення видобувних свердловин доцільно продовжувати їх експлуатацію, здійснюючи спільний видобуток газу разом із водою, що, в свою чергу, сповільнить просування пластової води в продуктивні поклади та попередить защемлення залишкового газу водою [33].

В умовах пружноводонапірного режиму, який зумовлює просування води в поклад і появу ऑii в продукції свердловин, останні виводяться $з$ експлуатації після відносно невеликих відборів газу. Це пов'язано 3 особливостями промислового облаштування газових та газоконденсатних родовищ, які за технологічних i економічних міркувань зазвичай не розраховані на збір і підготовку газу з великим вмістом води.

Для зменшення витрат на утилізацію значних об'ємів пластових вод Р. М. Кондратом, I. М. Фиком та В. С. Григор'євим на основі результатів проведених досліджень $[2,30]$ запропоновано технологію [34] видобування газу із закачуванням газорідинної суміші з обводнених покладів в газоконденсатні поклади, які характеризуються пониженими пластовими тисками. Для реалізації даної технології в обводнених свердловинах, які розміщені в основному в периферійних частинах покладу, додатково пропонується розкривати виснажений газоконденсатний поклад і здійснювати перепуск газорідинної суміші в обводнений поклад. В результаті відбору води тиск в обводненій частині покладу знижується до тиску початку руху газу защемленого водою. Таким чином, забезпечивши рухомість защемленого газу, починають його видобуток низкою видобувних свердловин в склепінній частині покладу. Реалізація даної технології забезпечить зменшення витрат на утилізацію пластової води, а також забезпечить продовження термінів розробки газових та газоконденсатних покладів, забезпечуючи при цьому високі коефіцієнти вуглеводневилучення.

Для збільшення коефіцієнтів вуглеводневилучення за результатами проведених лабораторних та аналітичних досліджень в ІФНТУНГ розроблений абсолютно новий підхід до розробки родовищ, який передбачає комплексний активний вплив на продуктивний пласт, привибійну зону пласта та стовбур свердловини. За результатами проведених досліджень авторами було встановлено закономірності поведінки природного защемленого газу при зниженні тиску. Дані залежності використані для створення нових та вдосконалення існуючих технологій регулювання просування пластових вод $\mathrm{i}$ збільшення при цьому коефіцієнта вилучення газу [35].

Враховуючи механізм поведінки защемленого газу, запропоновано нову технологію розробки газових та газоконденсатних родовищ, складовою частиною якої є здійснення протилежних операцій порівняно 3 відомою технологією. Грунтується нова технологія на збільшенні темпів відбору пластової води з обводнених свердловин, що призводить до зниження пластового тиску. При цьому темп відбору пластової води повинен бути більшим за темп іiі надходження.

Ефективність удосконаленої технології впливу на просування пластових вод при водонапірному режимі підтверджена численними дослідженнями на основі проведених експериментів для умов родовищ України та Російської Федерації [36, 37].

Найбільш досконалим методом розрахунку ефективності просування пластової води в продуктивний пласт, що виникає при зниженні пластового тиску в результаті виснаження родовища, є запропонований в 1949 році метод Ван Евердінгена і Херста [38]. Даний метод заснований на припущенні, що тиск в області початкового газоводяного контакту зменшуєть- 
ся на кінцеву величину $\Delta \mathrm{p}$ і потім підтримується на цьому низькому рівні, внаслідок чого обмежується приплив води в законтурну зону. Зниження тиску поділяється на серію дискретних кроків, а загальний приплив в будь-який момент часу складається 3 суми окремих припливів на кожному кроці. Для розрахунку за методом Херста та Ван Евердінгена достатньо звичайного калькулятора, що робить його простим і доступним у використанні [39].

Що стосується «прямих» методів, то до них відносять метод Фетковіча [40]. Однак найбільш простим та застосовуваним методом вважався метод Картера та Трейсі [41]. Цей метод досить простий і точний та використовується в комерційних чисельних симуляторах, однак має деякі певні особливості.

Відмінність методу Картера-Трейсі, що описує приплив води в пласт, від методу Херста-ван Евердінгена полягає в тому, що метод Картера-Трейсі базується на рівнянні дифузії при постійному кінцевому дебіті, а метод Херста-ван Евердінгена - на рівнянні при постійному кінцевому тиску.

Також до основних методів розрахунку ефективності просування пластової води в продуктивний пласт відносять метод «підгонки» Хавле-Оуде для водоносного пласта. Суть даного методу полягає в комбінуванні даних PVT-аналізу, історії видобутку вуглеводнів і даних про динаміку пластового тиску для «підгонки» моделі течії в законтурній області.

Часткове обводнення високопроникних пластів призводить до накопичення рідини на вибої свердловин через низьку швидкість газорідинного потоку. Накопичення рідини на вибої зумовлює зниження продуктивності свердловин [42]. Враховуючи той факт, що свердловини експлуатуються в режимі накопичення тиску i винесення води 3 свердловини має пульсаційний характер, визначення водного фактору $є$ не зовсім коректним і має тільки оціночний характер [30]. Саме тому забезпечення умов винесення рідини 3 вибою експлуатаційних свердловин може значно покращити основні технологічні параметри експлуатації свердловини та забезпечити іiі стабільну експлуатацію [43].

Для забезпечення стабільних дебітів свердловин необхідно вдосконалювати існуючі та розробляти нові методики розрахунків оптимальних технологічних режимів експлуатації свердловин, які забезпечать оперативне прийняття рішень щодо стабілізації їх експлуатації.

Відомі дослідники Тер-Саркисов Р.М., Илатовский Ю.В., Бузинов С.Н., Медко В.В.,
Харитонов А.Н., Нифантов В.И., Казарян В.П., Серегина Н.В. стверджують, що в умовах періоду спадаючого видобутку знижується енергетичний потенціал продуктивних пластів [44]. Завершальна стадія розробки родовищ характеризуються інтенсивним обводненням продуктивних покладів та експлуатаційних свердловин. Збільшення дебітів свердловин неможливе в умовах виснаження пластової енергії через обмеження подачі та підготовки вуглеводневої продукції за існуючої наземної інфраструктури. Зниження робочих тисків на устях свердловин та збільшення депресії на пласти можливе за рахунок введення дотискуючих компресорних станцій (ДКС), що потребує значних капіталовкладень.

Дуже часто оптимізація умов експлуатації низьконапірних свердловин забезпечується використанням устьових компресорних установок та глибинних струминних насосів, які забезпечують пониження тиску на устях та вибоях свердловин для підвищення продуктивності свердловин.

Перспективним також $\epsilon$ розроблений у ВНДІгаз спосіб експлуатації свердловин за концентричного дворядного ліфта (труба в трубi). На сьогоднішній день даний спосіб експлуатації низькодебітних свердловин активно впроваджується на Шебелинському родовищі. Більшість свердловин Шебелинського газоконденсатного родовища експлуатується в умовах накопичення рідини на вибоях свердловин, оскільки свердловини обладнані ліфтовою колоною умовним діаметром 73 мм, а середній пластовий тиск в продуктивних покладах складає близько 1,5-2 МПа. На основі аналізу експлуатації низькодебітного фонду свердловин обгрунтовано оптимізацію їх експлуатації шляхом обладнання колоною сифонних трубок, виготовлених $з$ полікомпозитних матеріалів.

За результатами досліджень та освоєння таких свердловин вдалося досягти збільшення дебіту газу в 2-3 рази. Діаметр сифонної трубки вибирається таким чином, щоб забезпечити умови винесення газорідинної суміші 3 вибою свердловин. Для підвищення ефективності даної технології розроблені спеціальні технічні засоби, які дозволяють керувати процесом оптимізації експлуатації свердловини в автоматичному режимі.

На даний час провідні світові компанії інтенсивно вивчають проблеми, пов'язані $з$ експлуатацією низьконапірних свердловин, новітні технології інтенсифікації видобутку вуглеводнів 3 низьконапірних свердловин $з$ метою дорозробки виснажених обводнених газових і газо- 


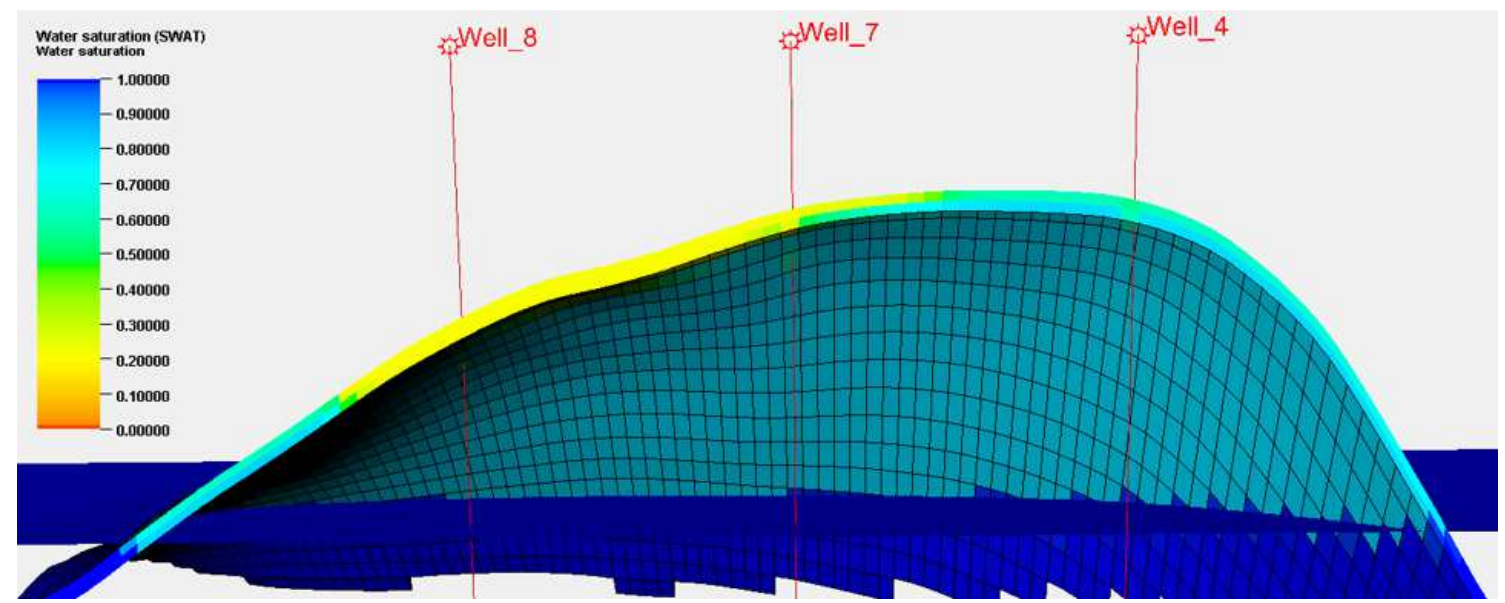

Рисунок 2 - Характер обводнення неоднорідних продуктивних покладів

конденсатних родовищ [45]. Напрацювання провідних фахівців інтенсивно впроваджуються та дають позитивний ефект.

Одним 3 пріоритетних напрямів досліджень газових та газоконденсатних родовищ 3 метою підвищення якості проектування і оцінки ефективності реалізації проектних рішень, а також управління і контролю за повнотою виконання запланованих робіт $є$ використання чисельного моделювання.

3 метою напрацювання оптимальних шляхів підвищення вуглеводневилучення 3 виснажених обводнених газоконденсатних покладів проведено значну кількість досліджень із використанням основних інструментів моделювання.

За результатами численних лабораторних та експериментальних досліджень розкрито механізм поведінки защемленого газу водою в пористому середовищі. На основі результатів проведених досліджень розроблено нові та вдосконалено існуючі технології розробки продуктивних покладів за таких умов. Однак, враховуючи значну неоднорідність покладів вуглеводнів як за площею, так і за товщиною, розроблені технології можуть бути малоефективними. Характер розподілу фільтраційно-ємнісних властивості колектору вносить значну невизначеність у процес обгрунтування оптимальної технології подальшої розробки родовища в умовах активного пружноводонапірного режиму.

Приклад вибіркового обводнення газоконденсатного покладу в залежності від розподілу фільтраційно-ємнісних властивостей порідколекторів за товщиною наведена на рисунку 2.

3 метою оцінки можливого впливу анізотропії пластів на характер обводнення видобувних свердловин проведено дослідження розробки неоднорідного продуктивного покладу 3 підошовною водою. Використовуючи цифрову модель, проведено розрахунок десяти різних сценаріїв розробки продуктивних покладів. В якості досліджуваних параметрів виступали співвідношення вертикальної проникності до горизонтальної, оптимальний час експлуатації та зупинки свердловини, а також величина водного фактору.

За результатами проведених розрахунків встановлено, що чим менший коефіцієнт вертикальної проникності колектора, тим менший негативний вплив конусоутворення на процес експлуатації видобувних свердловин. Отримані результати моделювання свідчать про те, що у випадку високої проникності та активної водонапірної системи защемлюються великі об' єми газу. Згідно результатів моделювання сумісний видобуток води та газу забезпечує значно вищі коефіцієнти вуглеводневилучення. Однак, отримані при цьому великі об'єми води в подальшому потребують утилізації, що призводить до додаткових затрат. На сьогоднішній момент концепція безводного видобутку вуглеводнів $\epsilon$ домінуючою. За результатами моделювання розробки Оренбурзького родовища доведено економічну та технологічну ефективність сумісного видобутку води та газу. Величини коефіцієнтів вуглеводневилучення залежать як від параметрів продуктивного пласта, так і від прийнятих технологічних обмежень та рішень [46].

Для напрацювання оптимальних шляхів вилучення защемленого газу здійснено моделювання процесу видобутку защемленого газу 3 використанням цифрової моделі. На основі цифрової моделі досліджено поведінку защемленого газу в пористому середовищі в залежності від фазової проникності для газу та капілярних тисків. За результатами моделювання напрацьовано методологічний підхід до моделювання видобутку защемленого газу та коректної оцінки перспектив вуглеводневилучення [47]. 
Чисельне моделювання розробки північносхідного родовища Хічкока, що розташоване в штаті Техас, дозволило вдосконалити існуючу технологію дорозробки обводнених покладів родовища, забезпечивши при цьому значно вищі кінцеві коефіцієнти вуглеводневилучення. Саме постійно діюча тривимірна модель дозволила визначити пластовий тиск, за якого газ, защемлений водою, мобілізується, та обгрунтувати технологію його вилучення 3 продуктивних покладів. Розрахунок різних варіантів розробки родовища, дозволив обгрунтувати оптимальні темпи відбору вуглеводневої продукції та вибрати раціональну систему розробки родовища [48].

Для підтвердження доцільності впровадження технологій вторинного видобутку вуглеводнів змодельовано розробку обводненого продуктивного покладу та досліджено процес витіснення защемленого газу діоксидом вуглецю 3 метою збільшення кінцевого коефіцієнта вуглеводневвилучення. Для підтвердження ефективності цієї технології на базі тривимірної моделі розраховано два варіанти розробки родовища в умовах пружноводонапірного режиму, які включають розробку родовища на виснаження та 3 нагнітанням діоксиду вуглецю на межі газоводяного контакту. Результати моделювання показали, що при закачуванні діоксиду вуглецю видобуток види скоротився приблизно на $60 \%$ порівняно з варіантом розробки родовища на виснаження. Завдяки закачуванню діоксиду вуглецю приплив та просування води стали контрольованими, що забезпечило значно кращі коефіцієнти вуглеводневилучення. Коефіцієнт вилучення газу збільшився на $10 \%$, а коефіцієнт вилучення конденсату на $4 \%$ порівняно з варіантом на виснаження [20].

Числові тривимірні композиційні моделі дозволяють дослідити ефективність використання різного роду невуглеводневих газів в якості агентів нагнітання 3 метою витіснення залишкового газу для забезпечення високих коефіцієнтів вуглеводневилучення.

Дослідження ефективності витіснення залишкового газу різними агентами нагнітання проведено на тривимірній моделі газоконденсатного родовища, яке характеризується пружноводонапірним режимом та знаходиться поблизу гірського хребта Сьерра-де-Чьяпас в Мексиці. В якості агентів нагнітання використано сухий газ, діоксид вуглецю, азот та димові гази. Отримані результати свідчать про те, що найефективнішим $є$ варіант 3 нагнітання діоксиду вуглецю. Завдяки впровадженню даної технології видобувається частина защемленого газу водою. В зонах нагнітання діоксиду вуглецю різко зростає пластовий тиск та створюється додатковий гідродинамічний бар'єр, що ускладнює просування пластової води в продуктивні пласти. Впровадження технології підтримання пластового тиску призводить до збільшення видобутку конденсату та забезпечує значно вищі коефіцієнти вуглеводневилучення. У випадку нагнітання діоксиду вуглецю досягається $80 \%$ вилучення конденсату а при нагнітанні сухого газу - 60\%. При використанні димових газів як агентів нагнітання кінцевий коефіцієнт вилучення конденсату знаходиться в межах 55$60 \%$. Найменш ефективним варіантом згідно результатів моделювання для конкретного родовища виявився варіант 3 нагнітанням азоту, однак отримані результати моделювання потрібно підтвердити лабораторними дослідженнями [49].

Моделювання розробки виснажених родовищ вуглеводнів, які перебувають на завершальній стадії розробки та розробляються в умовах пружноводонапірного режиму, дає можливість набути досвіду в застосуванні складних методик для прогнозування видобутку вуглеводнів 3 таких родовищ та дозволить встановити, що саме необхідно зробити для стабілізації видобутку газу в останні роки завершального етапу розробки.

Стратегія подальших робіт може включати буріння нових свердловин для залучення в розробку мікро- та макрозащемленого газу, удосконалення способу експлуатації свердловин та оптимізацію умов експлуатації.

На завершальних стадіях розробки виснажених родовищ використовуються різні технології підвищення коефіцієнтів вуглеводневилучення. Доцільність та ефективність вибраних методів та технологій залежить виключно від співвідношення необводненої та обводненої продуктивної площі родовища. Також при проектуванні розробки важливою $\epsilon$ інформація щодо переміщення контурних та підошовних вод. На характер просування газоводяного контакту значно впливає неоднорідність продуктивного розрізу, який складається здебільшого із порід, що характеризуються мінливістю фільтраційно-ємнісних властивостей як за товщиною, так і за площею [50].

За допомогою розрахунку різних сценаріїв розробки родовища і використовуючи постійно діючу геолого-технологічну модель родовища, можна порівняти ефективність кожного можливого заходу та оцінити економічну ефективність робіт. 
За таких умов необхідно розширювати область фундаментальних досліджень з розробки родовищ в умовах пружноводонапірного режиму, який характеризується різним рівнем інтенсивності просування пластової води в продуктивні пласти та призводить до виведення свердловин 3 діючого фонду. Метою майбутніх досліджень повинно стати вдосконалення існуючих технологій розробки родовищ на завершальній стадії з метою забезпечення максимальних коефіцієнтів вилучення вуглеводнів при мінімальних витратах з урахуванням зменшення навантаження на надра та навколишнє середовище.

\section{Висновок}

Безаварійна та стабільна експлуатація газових та газоконденсатних свердловин виснажених родовищ, які перебувають на завершальній стадії в умовах обводнення, $є$ надзвичайно актуальною.

На даний час проведено значну кількість теоретичних та експериментальних досліджень, пов'язаних 3 розробкою виснажених родовищ вуглеводнів в умовах пружноводонапірного режиму. За результатами вітчизняних та іноземних досліджень розкрито механізм поведінки защемленого газу водою в пористому середовищі. Спираючись на результати фундаментальних досліджень, розроблено значну кількість технологій розробки виснажених родовищ в умовах інтенсивного просування пластової води, які характеризуються певними перевагами та недоліками. Зважаючи на це, існує необхідність у систематизації існуючих технологій для різних геолого-технологічних умов розробки газоконденсатних родовищ та експлуатації свердловин $з$ подальшим розробленням нових технологій, які б за мінімальних витрат забезпечували максимальні коефіцієнти вилучення вуглеводнів, а також впровадження яких, 3 економічної точки зору, забезпечували б максимальний накопичений приведений грошовий потік.

Враховуючи вищенаведене, доцільно створювати постійно діючі геолого-технологічні моделі, які дозволять оптимізувати дорозробку виснажених газових та газоконденсатних родовищ в умовах пружноводонапірного режиму. Отримання точної адаптації моделі до фактичних даних та точного відтворення процесу прориву води в продуктивні поклади та свердловини дозволить встановити локалізацію залишкового защемленого газу та напрацювати шляхи їх вилучення з метою забезпечення максимальних коефіцієнтів вуглеводневилучення.

\section{Jimepamypa}

1. Бойко В.С., Кондрат Р.М., Яремійчук Р.С. Довідник 3 нафтогазової справи. К.: Львів, 1996. $620 \mathrm{c}$.

2. Кондрат Р. М. Газоконденсатоотдача пластов. М.: Недра, 1992. 255 с.

3. Бойко В. С., Бойко Р. В., Кеба Л. М., Семінський О. В. Обводнення газових і нафтових свердловин. Київ: Міжнародна економічна фундація, 2006. 791 с. ISBN 966-96506-2-3.

4. Матківський С. В., Кондрат О. Р., Кривуля С. В. та ін. Особливості оцінки дренованих запасів газу щільних колекторів. Нафтогазова енергетика. 2020. №. 1(33). С. 19-28.

5. Матківський С. В., Кондрат О. Р., Хайдарова Л. І. та ін. Дослідження впливу незначного прояву водонапірної системи на достовірність матеріального балансу колекторів. Розвідка та розробка нафтових і газових родовищ. 2020. №2 (75). C. 43-51.

6. Glumov D. N., Sokolov S. V., Strekalov A. V. Assessment of Drained Gas Reserves in the Process of Gas and Gas Condensate Field Operation in Water Drive (Russian). SPE Russian Petroleum Technology Conference, 16-18 October, Moscow, Russia, 2017

7. Мирзаджанзаде А. Х., Баренблатт Г. И., Ентов В. М., Желтов Ю. В., Маргулов Г. В., Рассохин Г. В., Рыжик В. М. О возможном влиянии начального градиента на разработку газовых и газоконденсатных месторождений при водонапорном режиме. Изв. ВУЗов, сер. Нефть и газ, 1970, № 1.

8. Zavaleta S., Adrian P. M., Michel Michel: Estimation of OGIP in a Water-Drive Gas Reservoir Coupling Dynamic Material Balance and Fetkovich Aquifer Model. SPE Trinidad and Tobago Section Energy Resources Conference, 25-26 June, Port of Spain, Trinidad and Tobago, 2018.

9. Geffen T. M., Parrish D. R., Haynes G. W., Morse R. A. Efficiency of gas displacements from porous media by liquid flooding. Trans. AIME. 1952. V. 195. P. 37-46.

10. Кондрат О. Р. Видобуток защемленого газу 3 обводнених родовищ. Тези наук.-техн. конф. проф.-викл. складу ун-ту нафти $i$ газу. Івано-Франківськ: ІФНТУНГ, НДІ НГТ, 1997. C. 6 .

11. Кондрат Р.М. Активний вплив на процеси розробки родовищ природних газів 3 водонапірним режимом для збільшення газоконденсатовилучення. Наука та інноващіï. 2005. T. 1. № 5. C. 12-23.

12. Geffen T. M., Parrish D. R., Haynes C. W., Morse R. A. Efficiency of Gas Displacement from 
Porous Media by Liquid Flooding'. Trans., AIME. 1952. Vol 195. P. 29-38.

13. Chierici G. L., Ciocci G. M., Long G.: Experimental Research on Gas Saturation Behind the Water Front in Gas Reservoirs Subjected to Water Drive. Proc. Sixth World Pet. Conf., Frankfurt (1963) Sec IV Paper 17-PD6. 483 498,

14. Agarwal R.G., Al-Hussamy R., Ramey H.J. The Importance of Water Influx in Gas Reservoirs. Jour. Pet. Tech. (November, 1965) 1336-1342. Trans., AIME. 234.

15. Knapp R.M. et al. Calculation of Gas Recovery Upon Ultimate Depletion of Aquifer storage. JPT (Oct. 1968) 1129- 32.

16. Hower T. L., Bcrgeson I. E., Lewis D. R. Owens R. W. Recovery Optimization in a MultiReservoir Offshore Gas Field with Water Influx, SPE 24865, 67th Annual Technical Conference and Exhibition of the Society of Petroleum Engineers held in Washington D.C., Oct. 4-7, 1992. P. 9-15.

17. Rogers L. A. Test of Secondary Gas Recovery by Coproduction of Gas and Water from Mt. Selman Field, Texas. SPE. DOE/GRI 12865, Unconventional Gas Recovery Symposium held in Pittsburgh. P. A., May 13-15, 1984. P. 331-335.

18. Rczaee M., Rostami B., Mojarad M. Experimental Determination of Optimized Production Rate and its Upscaling Analysis in Strong Water Drive Gas Reservoirs. IPTC 16938, International Petroleum Technology Conference held in Beijing. China. 26-28 March, 2013, P. 1-11.

19. Sim S. S. K., Turtata A. T., Singhai A. K. and Hawkins B. F. Enhanced Gas Recovery: Factors Affecting Gas-Gas Displacement Efficiency, Canada International petroleum Conference, June 17- 19, 2008. Calgari, Alberta, Canada. P. 1-14.

20. Ogolo N.A., Isebor J.O., Onyekonwu M.O. Feasibility Study of Improved Gas Recovery by Water Influx Control in Water Drive Gas Reservoirs. SPE Nigeria Annual International Conference and Exhibition, 5-7 August, Lagos, Nigeria, 2014.

21. Кондрат О. Р., Кондрат Р. М. Підвищення газовилучення з газових родовищ при водонапірному режимі шляхом регулювання надходження законтурної пластової води і видобутку зещемленого газу. Нафтогазова галузь України. 2019. № 4. С. 21-26.

22. Бікман Є. С., Дячук В. В. Підвищення ефективності технології підтримання пластового тиску при розробці газоконденсатних покладів $з$ використанням азоту. Матеріали наукової конферениії “Нафта і газ України”. Київ, 2002. C. 23-24.
23. Бікман Є. С., Хомин І. І., Куль А. Й. Технологія розробки газоконденсатного родовища 3 підтриманням пластового тиску газоподібним азотом. Компресорное $и$ энергетическое машиностроение. 2008. № 2(12). С.26-30.

24. Бікман Є. С., Дячук В. В. Перспективи впровадження технології підтримання пластового тиску з використанням азоту на газоконденсатних родовищах НАК "Нафтогаз України". Компресорное и энергетическое машиностроение. 2010. № 2(20). С. 17-20.

25. Бікман С. С., Сойма Р. Й. та ін. Особливості розробки фаменських покладів Тимофіївського та Куличихинського НГКР з використанням сайклінг процесу в умовах вибіркового обводнення. Питання розвитку газової промисловості Украӥни: Наук-виробн. зб. 2017. XLV. C. 45-52.

26. Гиматудинов Ш. К. Физика нефтяного и газового пласта. М.: Недра, 1971. 309 с.

27. Мамедов Г. А., Фарзане Я. Г. О вытеснении газа (воздуха) водой из неоднороднослоистых пористых сред. Вестник Вузов. серия «Нефти и газ», 1964. №1. С.29-34.

28. Мирзаджанзаде А. Х. Дурмишьян А. Г., Ковалев А. Г. Разработка газоконденсатных месторождений. М.: Недра, 1967. 356 с.

29. Закиров С. Н., Коротаев Ю. П., Кондрат Р. М. и др. Теория водонапорного режима газовых месторождений. М: Недра, 1976. 240 с.

30. Рассохин Г. В., Леонтьев И. А., Петренко В. И. и др. Влияние обводнения многопластовых газовых и газоконденсатных месторождений на их разработку. М.: Недра, 1973. 264 с.

31. Закиров С. Н., Коротаев Ю. П., Кондрат Р. М. и др. Теория водонапорного режима газовых месторождений. М.: Недра, 1976. 240 с.

32. А.с 571107 СССР, МКИ Е21В 43/00. Способ добычи газа / Ю.П. Коротаев, С.Н. Закиров, Р.М. Кондрат и др. №2075239; Заявлено 12.11.1974; Зарегистр. 06.05.1977; Опубл. 07.11.1981, Б.И. №11.

33. Kondrat O. R., Kondrat R. M. Investigation of regularities of trapped gas recovery processes from watered gas fields with homogeneous and macro heterogeneous reservoirs. MINING OF MINERAL DEPOSITS, Taylor \& Francis Group, London, Uk, 2014, P. 303-309.

34. А.с 1314757 СССР, МКИ Е21В 43/00. Способ вторичной добычи газа / Р.М. Кондрат, Й.Н. Тонкой, И.М. Фык и др. №3956225; Заявлено 24.09.1985; Зарегистр. 01.02.1987.

35. Кондрат Р. М. Активний вплив на процеси розробки родовищ природних газів 3 водонапірним режимом для збільшення газокон- 
денсатовилучення. Наука та інновації. 2005. T. 1. №5. С. 12-23.

36. Многомерная и многокомпонентная фильтрация: Справочное пособие / С.Н. Закиров, Б.Е. Сомов, В.Я. Гордон и др. М: Недра, 1988. 335 c.

37. Прогнозирование и регулирование разработки газовых месторождений / Закиров С.Н., Васильев В. И, Гутников А. И. и др. М.: Недра, 1984. 295 c.

38. Dietz D. N. A Theoretical Approach to the Problem of Encroaching and By-Passing Edge Water, Akad. van Wetenschappen, Amsterdam, 1953, Proc. Vol. 56B: 83.

39. Nadir F. T: Thistle Field Development, SPE Europec Conference (EUR 165), October 1980.

40. Coats K. H., Dempsey J. R. and Henderson J. H. The Use of Vertical Equilibrium in Two Dimensional Simulation of Three Dimensional Reservoir Performance. Soc. Pet. Eng. J., March 1971. $63 \mathrm{p}$.

41. Thomas G.W. Principles of Hydrocarbon Reservoir Simulation, IHRDC Publishers, Boston, Mass., 1982. 160 p.

42. Севастьянов О. М. Захарова Е. Е. Особенности обводнения скважин и газоконденсатной залежи ОНГКМ. Газовая промьилленность. 2004. № 10. С. 80-82.

43. Gamal M., Khairy M., El-Banbi A. H., Saad S. M. An Approach for Determination of the Economically Optimal Production Controlling Parameters from Water Drive Oil Reservoirs. SPE Kingdom of Saudi Arabia Annual Technical Symposium and Exhibition, 25-28 April, Dammam, Saudi Arabia, 2016.

44. Тер-Саркисов Р. М., Илатовский Ю. В., Бузинов С. Н., Медко В. В., Харитонов А. Н., Нифантов В. И., Казарян В. П., Серегина Н. В. Особенности добычи низконапорного газа. Газовая промыиленность. 2005. № 11.

45. James F. Lea, Henry V. Nickens, Mike R. Wells. Gas well deliquification. Elsevier Inc., Second Edition, 2008.

46. Аникеев Д. П., Закиров С. Н., Кондрат А. Р. Возможности увеличения КИГ при разработке залежей газа с подошвенной водой. Газовая промышиенность. 2013. № 9(695). С. 51-53.

47. Babadimas J. M. Modelling Trapped Gas Expansion in Water-Drive Reservoirs/ SPE/IATMI Asia Pacific Oil \& Gas Conference and Exhibition, 17-19 October, Jakarta, Indonesia, 2017.

48. Ancell K. L., Manhart T. A. Secondary Gas Recovery From a Water-Drive Gas Reservoir: A Case Study, SPE Annual Technical Conference and Exhibition, 27-30 September, Dallas, Texas, 1987.

49. Jose Alejandro Cruz Lopez. Gas Injection As A Method For Improved Recovery In GasCondensate Reservoirs With Active Support. SPE International Petroleum Conference and Exhibition in Mexico, 1-3 February, Villahermosa, Mexico, 2000.

50. Тер-Саркисов Р. М. Разработка месторождений природных газов. М.: Недра, 1999. $659 \mathrm{c}$.

\section{References}

1. Boiko V. S., Kondrat R. M., Yaremiichuk R. S. Dovidnyk z naftohazovoi spravy. K.: Lviv, 1996. 620 p. [in Ukrainian]

2. Kondrat R. M. Hazokondensatootdacha plastov. M.: Nedra, 1992. 255 p. [in Russian]

3. Boiko V. S., Boiko R. V., Keba L. M., Seminskyi O. V. Obvodnennia hazovykh i naftovykh sverdlovyn. Kyiv: Mizhnarodna ekonomichna fundatsiia, 2006. 791 p. ISBN 96696506-2-3. [in Ukrainian]

4. Matkivskyi S. V., Kondrat O. R., Kryvulia S. V. ta in. Osoblyvosti otsinky drenovanykh zapasiv hazu shchilnykh kolektoriv. Naftohazova enerhetyka. 2020. No. 1(33). P. 19-28. [in Ukrainian]

5. Matkivskyi S. V., Kondrat O. R., Khaidarova L. I. ta in. Doslidzhennia vplyvu neznachnoho proiavu vodonapirnoi systemy na dostovirnist materialnoho balansu kolektoriv. Rozvidka ta rozrobka naftovykh $i$ hazovykh rodovyshch. 2020. No 2 (75). P. 43-51. [in Ukrainian]

6. Glumov D. N., Sokolov S. V., Strekalov A. V. Assessment of Drained Gas Reserves in the Process of Gas and Gas Condensate Field Operation in Water Drive (Russian). SPE Russian Petroleum Technology Conference, 16-18 October, Moscow, Russia, 2017

7. Mirzadzhanzade A. Kh., Barenblatt G. I., Entov V. M., Zheltov Yu. V., Margulov G. V., Rassokhin G. V., Ryzhik V. M. O vozmozhnom vliyanii nachal'nogo gradienta na razrabotku gazovykh i gazokondensatnykh mestorozhdenij pri vodonapornom rezhime. Izv. VUZov, ser. Neft' i gaz, No1, 1970. [in Russian]

8. Zavaleta S., Adrian P. M., Michel Michel: Estimation of OGIP in a Water-Drive Gas Reservoir Coupling Dynamic Material Balance and Fetkovich Aquifer Model. SPE Trinidad and Tobago Section Energy Resources Conference, 25-26 June, Port of Spain, Trinidad and Tobago, 2018.

9. Geffen T. M., Parrish D. R., Haynes G. W., Morse R. A. Efficiency of gas displacements from 
porous media by liquid flooding. Trans. AIME. 1952. V. 195. P. 37-46.

10. Kondrat O. R. Vydobutok zashchemlenoho hazu z obvodnenykh rodovyshch. Tezy nauk.-tekhn. konf. grof.-vykl. skladu unstytutu nafty $i$ hazu. Ivano-Frankivsk: IFNTUNH, NDI NHT, 1997. P. 6. [in Ukrainian]

11. Kondrat R. M. Aktyvnyi vplyv na protsesy rozrobky rodovyshch pryrodnykh haziv $\mathrm{z}$ vodonapirnym rezhymom dlia zbilshennia hazokondensatovyluchennia. Nauka ta innovatsii, 2005. Vol1. No 5. P. 12-23. [in Ukrainian]

12. Geffen T. M., Parrish D. R., Haynes C. W., Morse R. A. Efficiency of Gas Displacement from Porous Media by Liquid Flooding'. Trans., AIME. 1952. Vol 195. P. 29-38.

13. Chierici G. L., Ciocci G. M., Long G.: Experimental Research on Gas Saturation Behind the Water Front in Gas Reservoirs Subjected to Water Drive. Proc. Sixth World Pet. Conf., Frankfurt (1963) Sec IV Paper 17-PD6. 483 498,

14. Agarwal R.G., Al-Hussamy R., Ramey H.J. The Importance of Water Influx in Gas Reservoirs. Jour. Pet. Tech. (November, 1965) 1336-1342. Trans., AIME. 234.

15. Knapp R.M. et al. Calculation of Gas Recovery Upon Ultimate Depletion of Aquifer storage. JPT (Oct. 1968) 1129- 32.

16. Hower T. L., Bcrgeson I. E., Lewis D. R. Owens R. W. Recovery Optimization in a MultiReservoir Offshore Gas Field with Water Influx, SPE 24865, 67th Annual Technical Conference and Exhibition of the Society of Petroleum Engineers held in Washington D.C., Oct. 4-7, 1992. P. 9-15.

17. Rogers L. A. Test of Secondary Gas Recovery by Coproduction of Gas and Water from Mt. Selman Field, Texas. SPE. DOE/GRI 12865, Unconventional Gas Recovery Symposium held in Pittsburgh. P. A., May 13-15, 1984. P. 331-335.

18. Rczaee M., Rostami B., Mojarad M. Experimental Determination of Optimized Production Rate and its Upscaling Analysis in Strong Water Drive Gas Reservoirs. IPTC 16938, International Petroleum Technology Conference held in Beijing. China. 26-28 March, 2013, P. 1-11.

19. Sim S. S. K., Turtata A. T., Singhai A. K. and Hawkins B. F. Enhanced Gas Recovery: Factors Affecting Gas-Gas Displacement Efficiency, Canada International petroleum Conference, June 17- 19, 2008. Calgari, Alberta, Canada. P. 1-14.

20. Ogolo N.A., Isebor J.O., Onyekonwu M.O. Feasibility Study of Improved Gas Recovery by Water Influx Control in Water Drive Gas Reservoirs. SPE Nigeria Annual International
Conference and Exhibition, 5-7 August, Lagos, Nigeria, 2014.

21. Kondrat O. R., Kondrat R. M. Pidvyshchennia hazovyluchennia $\mathrm{z}$ hazovykh rodovyshch pry vodonapirnomu rezhymi shliakhom rehuliuvannia nadkhodzhennia zakonturnoi plastovoi vody i vydobutku zeshchemlenoho hazu. Naftohazova haluz Ukrainy. 2019. No 4. P. 21-26. [in Ukrainian]

22. Bikman Ye. S., Diachuk V. V. Pidvyshchennia efektyvnosti tekhnolohii pidtrymannia plastovoho tysku pry rozrobtsi hazokondensatnykh pokladiv z vykorystanniam azotu. Materialy naukovoi konferentsii "Nafta $i$ haz Ukrainy". Kyiv, 2002. P. 23-24. [in Ukrainian]

23. Bikman Ye. S., Khomyn I. I., Kul A. Y: Tekhnolohiia rozrobky hazokondensatnoho rodovyshcha z pidtrymanniam plastovoho tysku hazopodibnym azotom. Kompresornoe $i$ ehnergeticheskoe mashinostroenie. 2008. № 2(12). P. 2630. [in Ukrainian]

24. Bikman Ye. S., Diachuk V. V. Perspektyvy vprovadzhennia tekhnolohii pidtrymannia plastovoho tysku z vykorystanniam azotu na hazokondensatnykh rodovyshchakh NAK "Naftohaz Ukrainy". Kompresornoe $i$ enerhetycheskoe mashynostroenye. 2010. No 2(20). P. 17-20. [in Ukrainian]

25. Bikman Ye. S., Soima R. Y. ta in. Osoblyvosti rozrobky famenskykh pokladiv Tymofiivskoho ta Kulychykhynskoho NHKR z vykorystanniam saiklinh protsesu $\mathrm{v}$ umovakh vybirkovoho obvodnennia. Pytannia rozvytku hazovoi promyslovosti Ukrainy: Nauk-vyrobn. zb. 2017. XLV. P. 45-52.

26 Gimatudinov Sh. K. Fizika neftyanogo i gazovogo plasta. M.: Nedra, 1971. 309 p. [in Russian]

27. Mamedov G. A., Farzane Ya. G. O vytesnenii gaza (vozdukha) vodoj iz neodnorodnosloistykh poristykh sred. Vestnik Vuzov. seriya «Nefti i gaz». 1964. No 1. P. 29-34. [in Russian]

28. Mirzadzhanzade A.Kh. Durmish'yan A.G., Kovalev A. G. Razrabotka gazokondensatnykh mestorozhdenij. M.: Nedra, 1967. 356 p. [in Russian]

29. Zakirov S. N., Korotaev Yu. P., Kondrat R. M. i dr. Teoriya vodonapornogo rezhima gazovykh mestorozhdenij. M: Nedra, 1976. 240 p. [in Russian]

30. Rassokhin G. V., Leont'ev I. A., Petrenko V. I. i dr. Vliyanie obvodneniya mnogoplastovykh gazovykh i gazokondensatnykh mestorozhdenij na ikh razrabotku. M.: Nedra, 1973. 264 p. [in Russian] 
31. Zakirov S. N., Korotaev Yu. P., Kondrat R. M. i dr. Teoriya vodonapornogo rezhima gazovykh mestorozhdenij. M.: Nedra, 1976. 240 p. [in Russian]

32. A.s 571107 SSSR, MKI E21V 43/00. Sposob dobychi gaza / Yu.P. Korotaev, S.N. Zakirov, R.M. Kondrat i dr. №2075239; Zayavleno 12.11.1974; Zaregistr. 06.05.1977; Opubl. 07.11.1981, B.I. No 11. [in Russian]

33. Kondrat O. R., Kondrat R. M. Investigation of regularities of trapped gas recovery processes from watered gas fields with homogeneous and macro heterogeneous reservoirs. MINING OF MINERAL DEPOSITS, Taylor \& Francis Group, London, Uk, 2014, P. 303-309.

34. A.s 1314757 SSSR, MKI E21V 43/00. Sposob vtorichnoj dobychi gaza / R.M. Kondrat, J.N. Tonkoj, I.M. Fyk i dr. No 3956225; Zayavleno 24.09.1985; Zaregistr. 01.02.1987. [in Russian]

35. Kondrat R. M. Aktyvnyi vplyv na protsesy rozrobky rodovyshch pryrodnykh haziv $\mathrm{Z}$ vodonapirnym rezhymom dlia zbilshennia hazokondensatovyluchennia. Nauka ta innovatsii. 2005. T. 1. No 5. P. 12-23. [in Ukrainian]

36. Mnogomernaya i mnogokomponentnaya filtraciya: Spravochnoe posobie / S.N. Zakirov, B.E. Somov, V.Ya. Gordon i dr. M: Nedra, 1988. 335 p. [in Russian]

37. Prognozirovanie i regulirovanie razrabotki gazovykh mestorozhdenij / Zakirov S. N., Vasilev V. I, Gutnikov A. I. i dr. M.: Nedra, 1984. 295 p. [in Russian]

38. Dietz D. N. A Theoretical Approach to the Problem of Encroaching and By-Passing Edge Water, Akad. van Wetenschappen, Amsterdam, 1953, Proc. Vol. 56B: 83.

39. Nadir F. T: Thistle Field Development, SPE Europec Conference (EUR 165), October 1980.

40. Coats K. H., Dempsey J. R. and Henderson J. H. The Use of Vertical Equilibrium in Two Dimensional Simulation of Three Dimensional Reservoir Performance. Soc. Pet. Eng. J., March $1971.63 \mathrm{p}$.

41. Thomas G.W. Principles of Hydrocarbon Reservoir Simulation, IHRDC Publishers, Boston, Mass., 1982: 160.

42. Sevast'yanov O. M. Zakharova E. E. Osobennosti obvodneniya skvazhin i gazokondensatnoj zalezhi ONGKM. Gazovaya promyshlennost. 2004. No 10. P. 80-82. [in Russian]

43. Gamal M., Khairy M., El-Banbi A. H., Saad S. M. An Approach for Determination of the Economically Optimal Production Controlling Parameters from Water Drive Oil Reservoirs. SPE Kingdom of Saudi Arabia Annual Technical Sym- posium and Exhibition, 25-28 April, Dammam, Saudi Arabia, 2016.

44. Ter-Sarkisov R. M., Ilatovskij Yu. V., Buzinov S. N., Medko V. V., Kharitonov A. N., Nifantov V. I., Kazaryan V. P., Seregina N. V. Osobennosti dobychi nizkonapornogo gaza. Gazovaya promyshlennost'. 2005. No 11. [in Russian]

45. James F. Lea, Henry V. Nickens, Mike R. Wells. Gas well deliquification. Elsevier Inc., Second Edition, 2008.

46. Anikeev D.P., Zakirov S.N., Kondrat A.R. Vozmozhnosti uvelicheniya KIG pri razrabotke zalezhej gaza s podoshvennoj vodoj. Gazovaya promyshlennost'. 2013. No 9(695). P. 51-53. [in Russian]

47. Babadimas J. M. Modelling Trapped Gas Expansion in Water-Drive Reservoirs/ SPE/IATMI Asia Pacific Oil \& Gas Conference and Exhibition, 17-19 October, Jakarta, Indonesia, 2017.

48. Ancell K. L., Manhart T. A. Secondary Gas Recovery From a Water-Drive Gas Reservoir: A Case Study, SPE Annual Technical Conference and Exhibition, 27-30 September, Dallas, Texas, 1987.

49. Jose Alejandro Cruz Lopez. Gas Injection As A Method For Improved Recovery In GasCondensate Reservoirs With Active Support. SPE International Petroleum Conference and Exhibition in Mexico, 1-3 February, Villahermosa, Mexico, 2000.

50. Ter-Sarkisov P. M. Razrabotka mestorozhdenij prirodnykh gazov. M.: Nedra, 1999. 659 p. [in Russian] 